\title{
Is the eye a window to the brain in Sanfilippo syndrome?
}

\author{
Helen Beard ${ }^{1,2}$, Glyn Chidlow ${ }^{3}$, Daniel Neumann ${ }^{1,2}$, Nazzmer Nazri ${ }^{1,2}$, Meghan Douglass ${ }^{1}$, Paul J. Trim4, \\ Marten F. Snel ${ }^{4}$, Robert J. Casson ${ }^{3}$ and Kim M. Hemsley ${ }^{1,2^{*}}$
}

\begin{abstract}
Sanfilippo syndrome is an untreatable form of childhood-onset dementia. Whilst several therapeutic strategies are being evaluated in human clinical trials including i.v. delivery of AAV9-based gene therapy, an urgent unmet need is the availability of non-invasive, quantitative measures of neurodegeneration. We hypothesise that as part of the central nervous system, the retina may provide a window through which to 'visualise' degenerative lesions in brain and amelioration of them following treatment. This is reliant on the age of onset and the rate of disease progression being equivalent in retina and brain. For the first time we have assessed in parallel, the nature, age of onset and rate of retinal and brain degeneration in a mouse model of Sanfilippo syndrome. Significant accumulation of heparan sulphate and expansion of the endo/lysosomal system was observed in both retina and brain pre-symptomatically (by 3 weeks of age). Robust and early activation of micro- and macroglia was also observed in both tissues. There was substantial thinning of retina and loss of rod and cone photoreceptors by 12 weeks of age, a time at which cognitive symptoms are noted. Intravenous delivery of a clinically relevant AAV9-human sulphamidase vector to neonatal mice prevented disease lesion appearance in retina and most areas of brain when assessed 6 weeks later. Collectively, the findings highlight the previously unrecognised early and significant involvement of retina in the Sanfilippo disease process, lesions that are preventable by neonatal treatment with AAV9-sulphamidase. Critically, our data demonstrate for the first time that the advancement of retinal disease parallels that occurring in brain in Sanfilippo syndrome, thus retina may provide an easily accessible neural tissue via which brain disease development and its amelioration with treatment can be monitored.
\end{abstract}

Keywords: Retina, Mucopolysaccharidosis type III, Central nervous system, Eye, Lysosomal

\section{Introduction}

The temporal course of neurodegeneration in Sanfilippo syndrome or mucopolysaccharidosis type IIIA (MPS IIIA) is manifest by a normal infancy followed by progressive intellectual disability in early childhood and death at a median age of 18 years [43]. The most common of four subtypes of Sanfilippo syndrome in Australia [28], MPS IIIA results from an inherited, recessive mutation in the

\footnotetext{
*Correspondence: Kim.Hemsley@flinders.edu.au

${ }^{2}$ Present Address: Childhood Dementia Research Group, College of Medicine and Public Health, Finders Health and Medical Research Institute (FHMRI), Flinders University, Bedford Park, SA, Australia

Full list of author information is available at the end of the article
}

gene encoding the lysosomal exoenzyme sulphamidase (SGSH; EC 3.10.1.1), leading to incomplete degradation of heparan sulphate (HS), its accumulation in lysosomes and initiation of an inflammatory and degenerative cascade predominantly affecting the central nervous system (CNS).

Sanfilippo syndrome is presently untreatable, however several therapeutic approaches are under clinical evaluation in patients including but not limited to gene replacement $[11,19,40]$. The monitoring of both disease progression and therapeutic efficacy however, remains a significant obstacle and there is an urgent unmet need for

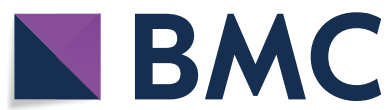

(c) The Author(s) 2020. This article is licensed under a Creative Commons Attribution 4.0 International License, which permits use, sharing, adaptation, distribution and reproduction in any medium or format, as long as you give appropriate credit to the original author(s) and the source, provide a link to the Creative Commons licence, and indicate if changes were made. The images or other third party material in this article are included in the article's Creative Commons licence, unless indicated otherwise in a credit line to the material. If material is not included in the article's Creative Commons licence and your intended use is not permitted by statutory regulation or exceeds the permitted use, you will need to obtain permission directly from the copyright holder. To view a copy of this licence, visit http://creativeco mmons.org/licenses/by/4.0/. The Creative Commons Public Domain Dedication waiver (http://creativecommons.org/publicdomain/ zero/1.0/) applies to the data made available in this article, unless otherwise stated in a credit line to the data. 
practical, non-invasive, and widely available techniques to be developed.

Significant retinal pathology occurs in utero in MPS III [6] with inclusions observed in photoreceptor cells, retinal ganglion cells and glia in the optic nerve. The electroretinogram (ERG) becomes abnormal in childhood [3, 9, 13, 27]. Gills and colleagues [13] reported retinal pigmentation, impairment of the ERG and night-blindness in two MPS III patients. In post-mortem specimens from adults with MPS III, vacuolation of the retina is observed, with photoreceptor degeneration. Haer-Wigman et al. [16] found mutations in the gene encoding the lysosomal enzyme defective in MPS IIIC (heparan acetyl-CoA: alpha-glucosaminide $\mathrm{N}$-acetyltransferase) in six adults with retinitis pigmentosa. Typical cognitive decline was not a clinical feature. This finding was recently verified in a cohort of 17 adults by Schiff and colleagues [35]. Coupled with the observation that retinal dysfunction is a common symptom in cognitively normal patients with later-onset MPS IIIA [29], these findings suggest that the retina requires a high level of lysosomal enzymes for normal function.

A significant loss of retinal function has been reported in MPS III mice as they age $[18,21,42]$. Of note, impairments to the dark-adapted ERG are evident, presumptively due to a loss of rod function, with lysosomal storage observed in Müller cells, disruption of the retinal pigment epithelium apparent from 4 weeks of age onwards, and subsequent photoreceptor degeneration. Tse et al. [42] reported that cone degeneration occurs much later in these mice (by 46 weeks of age). Emus with MPS IIIB have also been reported to exhibit vacuolisation of retinal ganglion cells [31].

Embryologically, the retina and optic nerve are outpouchings of brain and are part of CNS. Importantly, the retina is the only part of the CNS that can be visualised non-invasively. Given that many other neurological disorders exhibit retinal/optic nerve pathology prior to, or in conjunction with the onset of brain pathology [1, 24], we hypothesised that modern retinal and optic nerve imaging modalities may serve as an ideal biomarker both of progressive CNS disease in Sanfilippo syndrome and, potentially, therapeutic efficacy. The aim of the current study was to compare the temporal profiles of retinal and brain pathology and in short-term studies, determine the ability of a clinically relevant i.v.-delivered gene therapy approach to mediate improvements in disease sequelae in both neural tissues.

\section{Materials and methods Approvals}

The research protocol was approved by the Institutional Animal Ethics Committee (approvals \#1060/12/19 and $\# 1109 / 12 / 21)$ and the Institutional Biosafety
Committee (\#B144/12/20 and \#B149-12-21) prior to study commencement.

\section{Mice}

Congenic MPS IIIA mice (B6.Cg-Sgsh ${ }^{\text {mps3a) }}$ were obtained from a breeding colony established and maintained at the Women's and Children's Hospital Network, North Adelaide, South Australia, Australia. Congenic MPS IIIA mice were also intercrossed with a reporter line (Thy1-GFP M-line; [10]), purchased from Jax Mice to create MPS IIIA mice in which some retinal ganglion cells express green fluorescent protein (GFP).

All mice were group-housed in a constant temperature/humidity-controlled facility with a 14-h light:10-h dark cycle, with food and water ad libitum. Mice were provided with toilet rolls and plastic cups plus nesting material for environmental enrichment. All breeding, housing and experimental procedures complied with the Australian code for the care and use of animals for scientific purposes (8th edition; 2013) and the Association for Research in Vision and Ophthalmology (ARVO) statement (2016).

Genotyping for the SGSH mutation was undertaken on ear-notch tissue from which DNA was extracted (ThermoFisher Scientific), with subsequent PCR and restriction digest analysis performed according to methods in [26]. The genotypes of the GFP + mice were determined using customised Taqman $^{\circledR}$ XFP genotyping assays (Thermofisher Scientific). Forward (5' GCA CCA CCG GCA AGC T $3^{\prime}$ ) and reverse primers (5' AGT CGT GCT GCT TCA TGT GGT $\left.3^{\prime}\right)$ and allele-specific probes $\left(5^{\prime}\right.$ CCA CCC TGA CCT ACG $3^{\prime}$ ) were utilised. Reactions containing $2 \times$ TaqMan $^{\circledR}$ Genotyping Mastermix and $20 \times$ GFP-FAM primer were aliquoted into MicroAmp ${ }^{\circledR}$ fast optical 384-well reaction plates and $1 \mu \mathrm{L}$ DNA was added to each well ( $5 \mu \mathrm{L}$ total volume per well). Negative, no DNA template controls were included in each assay. The plates were sealed with MicroAmp ${ }^{\circledR}$ optical adhesive film and amplification performed on a QuantStudio 7 Flex Real-Time PCR system (Thermofisher Scientifc).

\section{Post-mortem extraction of tissues}

No differences have previously been found in the time of onset or rate of disease lesion progression in the brains of male or female mice with MPS IIIA, therefore, mice of mixed genders were humanely killed at 3, 6, 12, 15, 20, 22 or 25 weeks of age using asphyxiation with slow-fill $\mathrm{CO}_{2}$. Intra-cardiac perfusion with ice-cold saline was undertaken then brain, eyes and optic nerves were removed. Some brain tissue was dissected into five $2 \mathrm{~mm}$ hemi-coronal slices, with slice 1 containing olfactory bulb and the rostral aspect of the cerebral cortex and slice 5 containing cerebellum and brainstem. For mass spectrometry 
evaluation, the retina was carefully dissected from the eyes and both brain and retina were frozen at $-80{ }^{\circ} \mathrm{C}$ until used.

Brain tissue destined for immunohistochemistry was immersion-fixed in 4\% paraformaldehyde in PBS for up to 1 week. Eyes and optic nerves to be used for immunohistochemistry were immersion-fixed in Davidson's solution (2-parts 37\% formaldehyde, 3-parts 100\% ethanol, 1-part glacial acetic acid and 3-parts water) for $24 \mathrm{~h}$ and then held in 70\% alcohol for processing. Davidson's solution is the preferred fixative for whole eyes as it provides optimal tissue morphology while avoiding retinal detachment. A separate cohort of eyes was collected for retinal whole-mount preparation and was fixed in $4 \%$ PFA in PBS for $24 \mathrm{~h}$ before being placed in $30 \%$ sucrose at $4{ }^{\circ} \mathrm{C}$ until dissected as previously described [8].

To determine the impact of sulphamidase gene replacement on retinal and brain disease lesions, on the day of birth, cohorts of MPS IIIA and unaffected mice $(n=5 /$ group) received an intravenous injection of AAV9-CMVhSGSH or AAV9-CMV-GFP $\left(5 \times 10^{11} \mathrm{vg}\right.$; $\left.10 \mu \mathrm{L}\right)$ via the superficial temporal vein. A repeat injection was made via the tail vein on day 5 of life. Control mice of both genotypes received AAV-CMV-mCherry at this time. This sequential injection strategy increases the number of (newly emerging) retinal neurons exposed to viral vector [5]. Mice were weaned into same-sex groups at 3 weeks of age and were humanely killed as above at 6 weeks of age. Brain and both eyes were removed, and half of the brain and one eye was immersion-fixed in $4 \%$ paraformaldehyde and Davidson's fixative, respectively, as above. Prior to being frozen at $-80{ }^{\circ} \mathrm{C}$, the remaining brain hemisphere was divided into five $2 \mathrm{~mm}$ slices as above.

\section{Histology and immunohistochemistry}

Tissues were processed routinely into paraffin with brains and eyes embedded sagittally, and optic nerves longitudinally. Six micron-thick tissue sections were cut using a rotary microtome (Leica, Wetzlar, Germany) and mounted on glass slides (Superfrost ${ }^{\mathrm{TM}}$ Plus, Thermo Scientific, USA). Retinae were sectioned in a consistent manner to the level of the optic nerve head and brain sections were taken at approximately $0.48 \mathrm{~mm}$ lateral to the midline (according to the Mouse Brain Atlas [32]). Ovendried sections were deparaffinised in xylene, rinsed in two changes of $100 \%$ ethanol and gently washed in water. Haematoxylin and eosin staining was performed using standard methods.

Details of tissue type, antigen retrieval pre-treatment, primary antibody/lectin reagents used are outlined in Table 1. Biotinylated species-specific secondary antibodies, 1:2000 (Jackson ImmunoResearch Labs), Vectastain Elite $A B C$ kit reagents (PK-6100; Vector Laboratories, CA, USA) and the diaminobenzidine (DAB) liquid substrate chromagen system (\#3468; Dako, Glostrup

Table 1 Details of primary antibodies used for immunohistochemistry

\begin{tabular}{|c|c|c|c|c|}
\hline Primary antibody/Lectin & Catalogue number, Source & Dilution & Tissue type & Pre-treatment \\
\hline $\begin{array}{l}\text { Peanut agglutin lectin (PNA), } \\
\text { biotinylated }\end{array}$ & $\begin{array}{l}\text { \#B-1075, Vector Laboratories, } \\
\text { California, USA }\end{array}$ & $1: 3000$ & Retina, paraffin sections & $\begin{array}{l}\text { 20-min microwave, } 10 \text { mM citrate } \\
\text { buffer, } \mathrm{pH} 6\end{array}$ \\
\hline Mouse anti-rhodopsin & $\begin{array}{l}\text { \#MAB5316; Sigma-Aldrich Pty. } \\
\text { Ltd. NSW, Australia }\end{array}$ & $1: 600$ & Retina, paraffin sections & $\begin{array}{l}\text { 15-min microwave, } 10 \mathrm{mM} \\
\text { citrate,2 mM EDTA, 0.5\% Tween } \\
\text { 20, } \mathrm{pH} 6\end{array}$ \\
\hline $\begin{array}{l}\text { Rabbit anti-RNA-binding protein } \\
\text { with multiple splicing (RBPMS), }\end{array}$ & $\begin{array}{l}\text { \#ab194213; abcam, Victoria, } \\
\text { Australia }\end{array}$ & $1: 250$ & Retina, flat mounts & None \\
\hline Goat anti-calretinin & $\begin{array}{l}\text { \#AF5065; R\&D Systems Minne- } \\
\text { apolis, MN, USA }\end{array}$ & $1: 1500$ & Retina, paraffin sections & $\begin{array}{l}1 \text { mM EDTA, 0.05\% Tween 20, } \\
\text { pH8.0 15-min, microwave }\end{array}$ \\
\hline $\begin{array}{l}\text { Mouse anti-protein kinase } \\
\text { C-alpha (PKC-a) }\end{array}$ & \#ab31; abcam, Victoria, Australia & $1: 2000$ & Retina, paraffin sections & $\begin{array}{l}1 \text { mM EDTA, 0.05\% Tween 20, } \\
\text { pH8.0 15-min, microwave }\end{array}$ \\
\hline Mouse anti-calbindin & $\begin{array}{l}\text { \#C9848; Sigma-Aldrich Pty. Ltd. } \\
\text { NSW, Australia }\end{array}$ & $1: 1000$ & Retina, paraffin sections & $\begin{array}{l}1 \text { mM EDTA, 0.05\% Tween 20, } \\
\text { pH8.0 15-min, microwave }\end{array}$ \\
\hline \multirow[t]{2}{*}{$\begin{array}{l}\text { Mouse anti-lysosomal integral } \\
\text { membrane protein } 2 \text { (LIMP2) }\end{array}$} & In-house; Hemsley et. al., 2008 & $1: 500$ & Retina, paraffin sections & $\begin{array}{l}1 \text { mM EDTA, 0.05\% Tween 20, } \\
\text { pH8.0 15-min, microwave }\end{array}$ \\
\hline & & $1: 800$ & Brain, paraffin sections & $\begin{array}{l}\text { Target Retrieval Solution (DAKO), } \\
\text { 10- min microwave }\end{array}$ \\
\hline \multirow[t]{2}{*}{$\begin{array}{l}\text { Rabbit anti-glial gibrillary acidic } \\
\text { protein (GFAP) }\end{array}$} & $\begin{array}{l}\text { \#Z033401-2; Agilent (DAKO), } \\
\text { Santa Clara, CA, USA }\end{array}$ & $1: 500$ & Retina, paraffin sections & $\begin{array}{c}1 \text { mM EDTA, 0.05\% Tween 20, } \\
\text { pH8.0 15-min, microwave }\end{array}$ \\
\hline & & $1: 800$ & Brain, paraffin sections & $\begin{array}{l}\text { 10-min microwave, } 10 \text { mM citrate } \\
\text { buffer, pH } 6\end{array}$ \\
\hline $\begin{array}{l}\text { Isolectin-B4-peroxidase conju- } \\
\text { gated }\end{array}$ & $\begin{array}{l}\text { \#L5391; Sigma-Aldrich Pty. Ltd. } \\
\text { NSW, Australia }\end{array}$ & $1: 60$ & Brain and retina, paraffin sections & $\begin{array}{l}0.05 \% \text { Trypsin, pH } 7.615 \text { min @ } \\
37^{\circ} \mathrm{C}\end{array}$ \\
\hline
\end{tabular}


Denmark) were used to amplify and provide chromogenic visualisation.

Immunohistochemical staining of brain and ocular tissues was performed according to established methods $[4,7]$. Briefly, both eye and brain sections were deparaffinized and specific antigen retrieval performed prior to blocking of non-specific labelling with $10 \%$ normal donkey serum (NDS) in PBS. Sections were incubated overnight in primary antibody diluted in $2 \%$ NDS, washed in PBS and endogenous peroxidases blocked in $0.3 \%$ hydrogen peroxide. Sections were then incubated at room temperature in species-specific biotinylated secondary antibody, followed by Vectastain $\mathrm{ABC}$ reagent and colour detection was achieved by applying DAB.

For lectin histochemistry, sections underwent antigen retrieval and then were incubated in hydrogen peroxide followed by peroxidase-conjugated isolectin-B4 overnight. Colour detection was achieved using DAB. Terminal deoxynucleotidyl transferase dUTP nick end labelling (TUNEL) was carried out according to published methods [12, 33]. All staining was batched, and all analyses were conducted by a user blinded to mouse age, genotype, and treatment status. Sections were viewed on either an Olympus BX41 (with an Olympus UC50 camera), a BX61 microscope (with a ColourView III camera) or a Leica SP8X spectral scanning confocal microscope.

\section{Quantification of retinal thickness}

H\&E-stained sections were evaluated to determine the total thickness of the retina and that of individual retinal layers. To ensure inter-animal consistency, measurements were taken in two locations: $500 \mu \mathrm{m}$ from the ciliary body (representing "peripheral" retina) and $500 \mu \mathrm{m}$ from the optic nerve head (representing "central" retina). Measurements were made on each side of the optic nerve head and the mean thickness of the peripheral and central retina was calculated. For accuracy, retinal thickness measurements were only taken of sections in a perpendicular orientation. Total thickness was measured from the retinal ganglion cell layer (RGC) to, but not including, the retinal pigmented epithelium (RPE). Other measurements taken were the thickness of the inner plexiform layer (IPL), inner nuclear layer (INL), outer plexiform layer (OPL), outer nuclear layer (ONL), total photoreceptor segment layer (PS), inner segment layer (IS) and outer segment layer (OS). All measurements were carried out blind to genotype/age.

\section{Quantification of TUNEL and immunohistochemical labelling}

The number of positively stained cells in a specified length of retina or in a given area of brain were either counted manually or quantified using threshold analysis.
The relatively low number of TUNEL-positive nuclei were counted along the entire length and thickness of retinae. Peanut agglutinin-positive cone inner segment number were counted in a field of view using a 40X objective on each side of the central and peripheral retina. Calretinin positive amacrine cells were counted along $450 \mu \mathrm{m}$ of retina starting $150 \mu \mathrm{m}$ from each side of the optic nerve head. PKC $\alpha$-positive bipolar cells were counted in the central and peripheral retina, for a total length of $\sim 225 \mu \mathrm{m}$ on both sides of the optic nerve head. Due to their relatively low number, calbindin-positive horizontal cells were counted along almost the entire length of retina, starting one field of view from the ciliary body to within one field of view from the optic nerve head using a 40X objective. Cell counts were expressed as number of immuno-positive cells $/ \mathrm{mm}$. Threshold analysis of LIMP2 and GFAP staining, based on the optical density of positive immunostaining, is reported as \% immunoreactivity. Rhodopsin staining was undertaken for demonstration of rod outer segment changes however no quantification was performed.

\section{Preparation of flat mounts for evaluation of RGC number and dendritic arbour}

Immunolabelling with RBPMS was carried out on freefloating retinae, which were incubated in primary antibody for 3 days at room temperature, washed in PBS with $1 \%$ triton-X and then incubated in Alexafluor 488-labelled anti-rabbit secondary antibody for 1 day at $4{ }^{\circ} \mathrm{C}$. Following further washing in PBS/triton-X, retinae were mounted on glass slides using Vectashield anti-fade mounting medium with DAPI (\#H-1200, Vector Laboratories, Burlingame, USA) and stored in the dark. Flat mounts were evaluated on a confocal microscope (SP8X, Leica, Germany) with excitation provided by a $488 \mathrm{~nm}$ laser with emission captured with $493-569 \mathrm{~nm}$ filters for the green channel.

The density of RGCs was quantified in retinas taken from $n=6$ mice/genotype at each of 3, 6, 12 and 20 weeks of age. A further $n=3$ mice/genotype were aged to 25 weeks. Using a $\times 40$ objective, confocal z-stacks were taken through the RGC layer in three consistent regions in both central and peripheral retina. RGCs were counted manually using Cell counter available in AnalySIS Lifescience software (version 2.8, build 1235; Olympus Soft Imaging Solutions, Germany) and are presented as the number of cells $/ \mathrm{mm}^{2}$ of retina.

To evaluate RGC dendritic morphology, z-stack images of three $\mathrm{GFP}^{+}$RGCs per mouse ( $\mathrm{n}=3$ mice/genotype/ age; 3, 6, 12 and 20 weeks old) were obtained using a $20 \times$ objective to capture the entire dendritic tree. Images were imported into Fiji open-source image processing software [36] and dendritic morphology was assessed 
manually using plug-ins. A-type RGCs were identified based on morphological characteristics i.e. soma size, dendritic field size and the radiating pattern of branching as previously described [38]. Dendritic tree area was measured using the convex polygon tool to connect the distal tips of dendrites to form a polygon. Total dendritic length was determined using NeuronJ available in Fiji. and the total number of branches/nodes was determined using Cell counter. All analyses were performed by a user blind to mouse genotype and age.

\section{Mass spectrometry to quantitate stored heparan sulphate} Unfixed brain slices, optic nerve and retina were homogenised in $0.02 \mathrm{M}$ Tris/0.5 M NaCl, $\mathrm{pH} 7.4$, with HS disaccharides quantified using a previously published method [41]. Peak area ratios were determined using Analyst 1.6.2 software (ABSciex, Concord, Ontario, Canada), expressed per mg of total protein.

\section{Statistics}

Data are expressed as mean \pm SEM or as individual data points. Graphical and analytical exploratory data analyses were performed, and patterns assessed. To compare differences between unaffected and MPS IIIA mice at each time point, an un-paired Student's $t$-test with a Welch's correction was utilised. (GraphPad Prism version 8). Regression models with continuous scale outcome variables and time-dependant interaction effects were fitted to the data, and residuals analysed to validate the models' distributional assumptions. Multiple comparisons were handled with ANOVA and post-hoc Bonferroni correction. Data were regarded as statistically significant when $p<0.05$.

\section{Results}

Figure 1a-d shows representative photos of H\&Estained 25 week old unaffected and MPS IIIA mouse retinae. Total retinal thickness declined progressively in MPS IIIA mice (Fig. 1e). We observed no change in the thickness of the IPL (Fig. 1f) or INL (Fig. 1g) until MPS IIIA mice reached 25 weeks of age, however the OPL (Fig. 1h) exhibited thinning from 22 weeks of age, and the ONL (Fig. 1i) was notably thinner in affected mice from 12 weeks of age, a finding replicated when the number of photoreceptor cells was counted (Fig. 1j). TUNEL-positive, presumptively apoptosing cells were observed in the MPS IIIA mouse ONL, from 6 weeks of age with the peak period occurring around 12 weeks of age. (Fig. $1 \mathrm{k}-\mathrm{m}$ ).

Examining the ONL more closely (Fig. 2a, b) we noted fewer outer segments in both regions of retina in MPS IIIA mice as early as 6 weeks of age (Fig. 2d). Staining of rod photoreceptors with rhodopsin (Fig. 2e-h) and cone photoreceptors with peanut agglutinin (Fig. 2i-k) confirmed the early loss of both photoreceptor subtypes in affected mice. Thickening of the inner segments was noted in MPS IIIA mouse c.f. unaffected mouse retina (Fig. 2j).

In contrast, there was no significant change in the number of RBPMS-positive retinal ganglion cells (RGCs) in MPS IIIA retina to 25 weeks of age (Fig. $3 \mathrm{a}-\mathrm{c}$ ). The neurons had a soma diameter range of $17.8-31.5 \mu \mathrm{m}$ and a dendritic field diameter ranging from 189.2 to $468.8 \mu \mathrm{m}$, consistent with previous studies [34, 38]. To determine whether more discrete changes were present, we evaluated dendritic complexity (Additional file 1: Fig. S1A, B), a measure previously used to assess neuronal responses to injury, disease, or environmental conditions [2]. Overall, RGCs in the MPS IIIA mouse retina were found to retain their characteristic morphology and fine dendritic geometry and appeared largely unaffected by the disease process at least to 20 weeks of age (Additional file 1: Fig. S1C-F). Further, there was no convincing loss of calretinin-positive amacrine cells (Fig. $3 \mathrm{~d}-\mathrm{f}$ ) in MPS IIIA retina; the number of cells declined in mice of both genotypes with age. PKC- $\alpha$-labelled rod bipolar cells (Fig. 3gi) and calbindin-positive horizontal cells (Fig. 3j-l) also appeared largely resilient to the disease process.

We next quantified HS levels in retina, optic nerve and brain (Fig. 4a-c), and to confirm and visualise the impact of substrate accumulation, stained the tissues with a marker of the late endosome/lysosome compartment (lysosomal integral membrane protein, LIMP 2; Fig. $4 \mathrm{~d}-\mathrm{o}$ ). Significant and progressive accumulation of HS occurred in MPS IIIA mouse retina, optic nerve and brain from 3 weeks of age (c.f. levels in unaffected mouse tissues). Elevated LIMP 2 expression was also evident in retina, optic nerve and brain (staining quantified in the visual cortex and superior colliculus; Fig. 4f, i, l, o) from 3 weeks of age and the amount of immunoreactivity increased to 25 weeks of age in MPS IIIA mice.

Amoeboid, isolectin-B4-positive and therefore presumptively activated microglia were noted in MPS IIIA mouse retina and optic nerve, as well as visual cortex and superior colliculus from 3 weeks of age, the earliest time point evaluated (Fig. 5a-l). A cumulative increase in retinal and brain GFAP expression was noted in affected mice to 25 weeks of age (Fig. $6 \mathrm{a}-\mathrm{c}, \mathrm{g}-\mathrm{l}$ ); however, no change was observed in optic nerve (Fig. 6d-f).

Brain tissue from MPS IIIA mice exhibits increasing numbers of ubiquitin-positive axonal inclusions with age [4]. Whilst retina contained exceedingly few ubiquitin-positive structures (data not shown), axons in MPS IIIA mouse optic nerve exhibited immunoreactive spheroids that increased in number as the disease progressed (Additional file 2: Fig. S2A-C). 


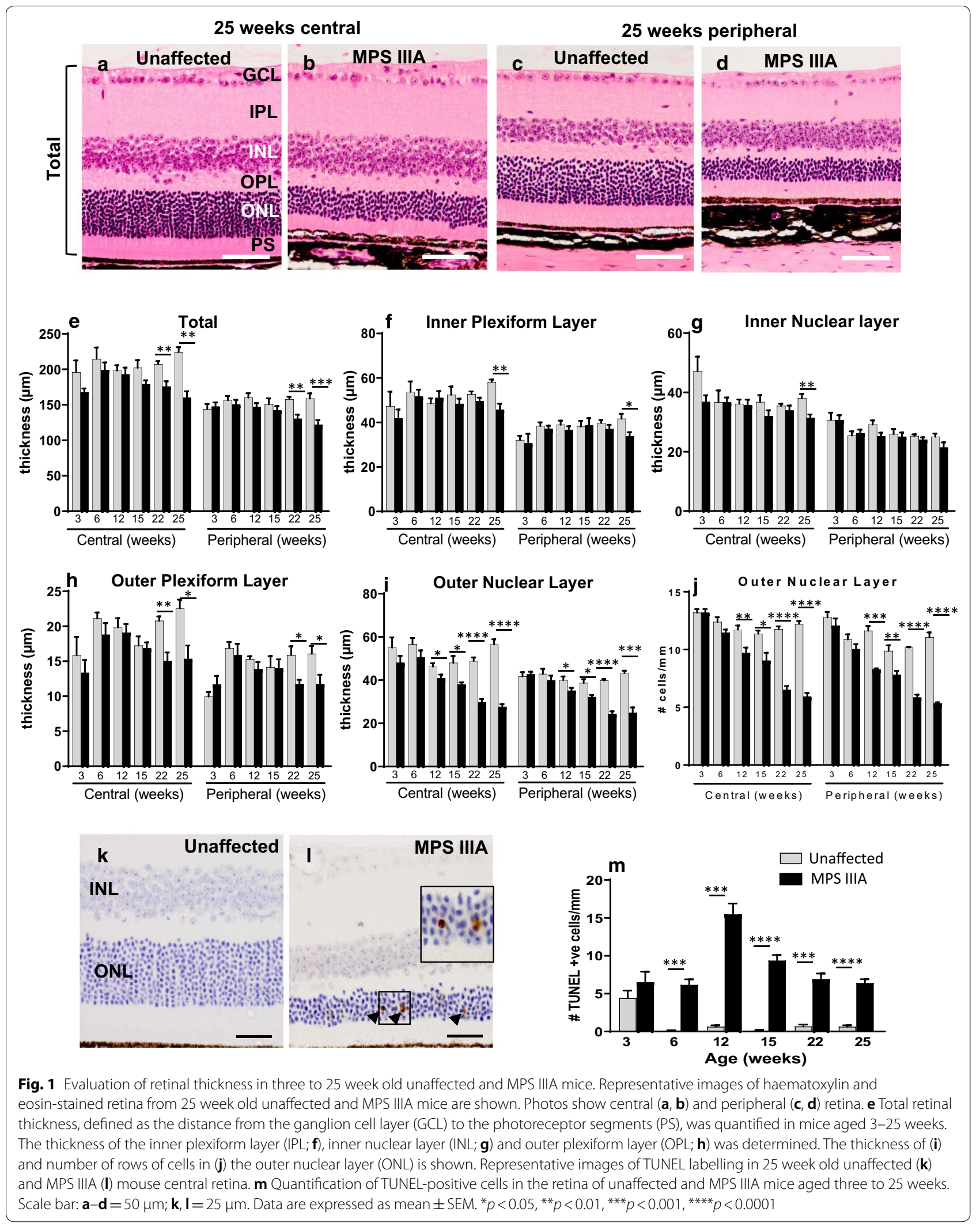



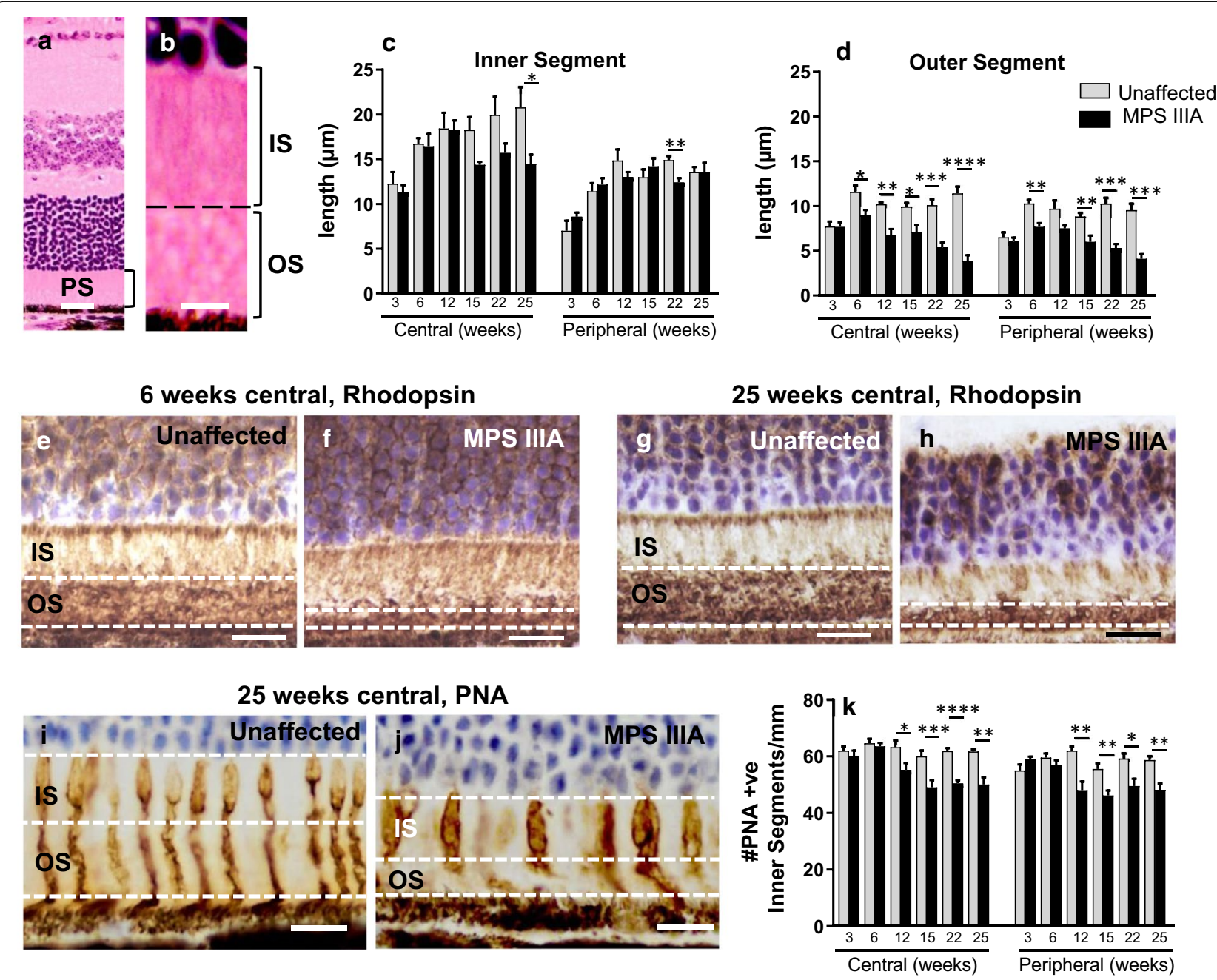

Fig. 2 Evaluation of the inner and outer segments in three to 25 week old unaffected and MPS IIIA mice. Haematoxylin and eosin-stained retina showing the photoreceptor segment (PS) layer (a), magnified in (b) to delineate inner (IS) and outer (OS) segments. Quantification of inner (c) and outer (d) segment length in central and peripheral retina. $\mathbf{e}-\mathbf{h}$ Representative images of rhodopsin immunostaining detailing rod outer segments in 6 and 25 week old unaffected and MPS IIIA mouse central retina. Peanut agglutin (PNA)-stained cone segments in 25 week old unaffected (i) and MPS IIIA (j) central retina. $\mathbf{k}$ Quantification of the number of PNA-stained inner segments. Scale bar; $\mathbf{a}=25 \mu \mathrm{m} ; \mathbf{b}=5 \mu \mathrm{m} ; \mathbf{e}-\mathbf{h}=20 \mu \mathrm{m} ; \mathbf{i}, \mathbf{j}=10 \mu \mathrm{m}$. Data are expressed as mean \pm SEM. ${ }^{*} p<0.05,{ }^{* *} p<0.01,{ }^{* * *} p<0.001,{ }^{* * * *} p<0.0001$

For retinal imaging to provide a non-invasive, quantitative method for visualising neurodegenerative changes in Sanfilippo syndrome, retinal disease must parallel brain disease. When we compared the rate of accumulation of HS (Fig. 7a), the rate of endo/lysosomal expansion (Fig. 7b, c), the appearance of activated microglia (Fig. 7d, e) or the number of GFAP-reactive macroglia (Fig. 7f, g) in MPS IIIA mouse brain to that in retina across the timeframe of the study, we found little difference between the two tissue types. LIMP2 accumulated at a statistically significantly slower rate in superior colliculus c.f. retina, but there was no difference in the rate of LIMP2 accumulation in visual cortex c.f. retina. Nor was there a difference in the rate of development of any of the other disease lesions in brain versus retina, with all other slopes found to be not significantly different to each other, suggesting the rate of disease lesion progression is equivalent in the two CNS tissue types.

Finally, given there is currently no effective therapy for patients with Sanfilippo syndrome, and any treatment strategy developed needs to be capable of preventing development of both brain and retinal disease lesions to afford patients maximum quality of life, we examined the short-term efficacy of i.v. delivery of AAV9-CMV-hSGSH to MPS IIIA mice at day 0 and 5 of life. One unaffected control mouse was cannibalised 


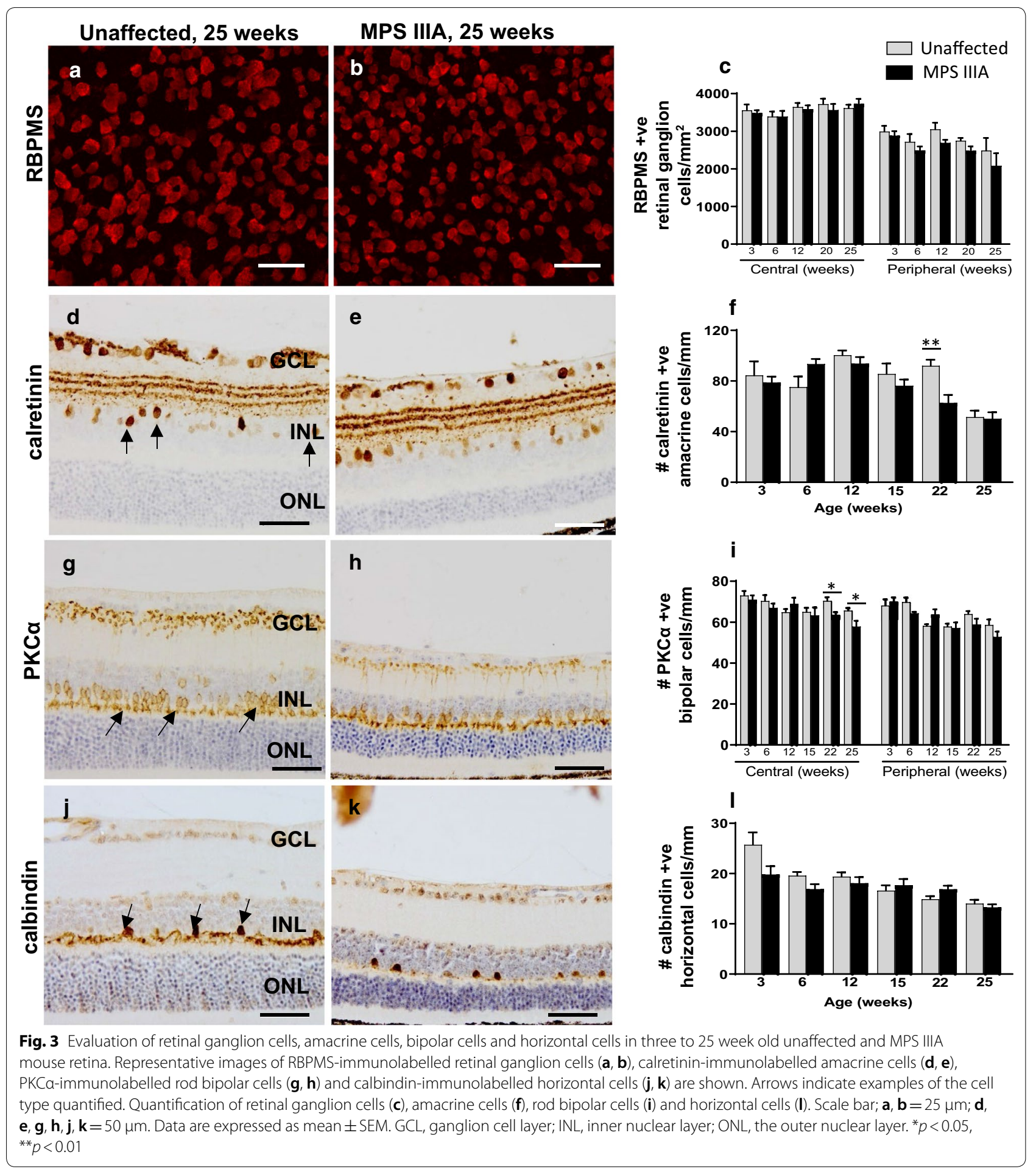

between day 0 and day 5 of life, however all other mice remained healthy post-injection. Mouse retina (Fig. 8a) and brain (Fig. 8b-f) was evaluated at 6 weeks postinjection. AAV9-CMV-hSGSH normalised the size of the endo/lysosomal compartment in MPS IIIA mouse retina and also in some (thalamus, rostral and medial aspects of cerebral cortex) but not all (inferior colliculus and brainstem) areas of brain examined and significantly reduced HS levels in brain (Fig. 8g-i). 
(See figure on next page.)

Fig. 4 Analysis of endo/lysosomal compartment expansion in unaffected and MPS IIIA mouse retina, optic nerve, and brain. Quantification of stored heparan sulphate in the retina (a), optic nerve $(\mathbf{b})$ and whole brain $(\mathbf{c})$ in three to 25 week old mice. Representative images of LIMP2 immunolabelling in 25 week old unaffected and MPS IIIA mouse retina $(\mathbf{d}, \mathbf{e})$, optic nerve $(\mathbf{g}, \mathbf{h})$, visual cortex $(\mathbf{j}, \mathbf{k})$ and superior colliculus ( $\mathbf{m}, \mathbf{n})$. Quantification of \% LIMP2 immunoreactivity in the retina (f), optic nerve (i), visual cortex (I) and superior colliculus (o). Scale bar; $\mathbf{d}, \mathbf{e}, \mathbf{g}, \mathbf{h}, \mathbf{j}, \mathbf{k}, \mathbf{m}$, $\mathbf{n}=50 \mu \mathrm{m}$. Data are expressed as mean \pm SEM. ${ }^{*} p<0.05,{ }^{* *} p<0.01,{ }^{* * *} p<0.001,{ }^{* * *} p<0.0001$

\section{Discussion}

Our goal was to establish the age at which disease lesions first become apparent in Sanfilippo mouse retina and brain and compare the rate of disease progression in each tissue in order to test the hypothesis that examination of the retina will provide insight into brain disease stage. In short-term studies, we then determined the ability of a clinically-relevant gene therapy approach to mediate improvements in disease sequelae in both neural tissues. Our objective is to ultimately provide a therapeutic monitoring strategy in addition to a prognostic tool, for children diagnosed with this devastating disorder. Whilst a few researchers have evaluated disease lesions in MPS III mouse retina, those studies have either started later in the disease course (three-plus months of age [21, 42]) or were qualitative in nature [18]. None have sought to compare brain and retinal disease with the goal of facilitating non-invasive evaluation of retina in order to inform understanding of brain disease.

For the first time, our study reveals that the age of onset and rate of progression of retinal disease in mice with MPS IIIA are remarkably similar to those in the brain. Both tissues exhibit substantial accumulation of heparan sulphate by 3 weeks of age, as determined by sensitive mass spectrometry-based measurements. HS levels in optic nerve were also elevated at this presymptomatic age. Primary storage of HS led to massive expansion of the late endosomal/lysosomal system in retina, optic nerve and brain as visualised using LIMP2staining. Similarly, the presence of presumptively activated isolectin-B4-positive microglia with an amoeboid morphology was noted in all three tissues in 3-weekold MPS IIIA mice. These cells remained present to the end of the study (mice aged 25 weeks) and were only rarely observed in unaffected mouse retina and optic nerve. Macrogliosis was observed from $\sim 6$ weeks of age in MPS IIIA mouse retina and brain although curiously, not in optic nerve. This may be explained by the fact that the optic nerve inherently expresses a high level of GFAP-astrocytic processes extend in all directions and through all planes of the optic nerve, rendering astrogliosis more challenging to quantify. Staining of axons in optic nerve with antibodies to ubiquitin revealed the appearance of axonal spheroids between 3 and 6 weeks of age, an observation that has also been made in brain [17]. Thus, the age of onset of disease lesions in MPS
IIIA mouse retina and brain is the same: $\sim 3$ weeks of age.

Disease lesion progression also occurs in parallel in the two structures. This suggests that methods that visualise and quantitate any of these lesions in MPS IIIA retina could inform clinicians about brain disease progression. Similarly, the efficacy of any treatment that is able to access retina as well as brain, for example i.v. AAV9sulphamidase as examined in the present study, or small molecule therapeutics such as anti-inflammatory agents e.g. Anakinra; IL-1R inhibitor, which is currently under clinical evaluation in Sanfilippo patients (www.clinicaltr ials.gov; NCT04018755), could ostensibly be visualised using non-invasive retinal imaging.

The possibility of using retinal lesions to inform our understanding of the degree of brain pathology is receiving increasing attention from researchers evaluating a range of neurodegenerative diseases, most notably Alzheimer's disease (AD). Koronyo-Hamaoui et al. [22] were first to describe the presence of $A \beta+$ plaques in $A D$ patient retinae, establishing a curcumin-based imaging strategy to facilitate the early diagnosis and prognosis of AD patients. This technique has recently been evaluated in humans with this disorder [23]. Tau oligomers are also present in retina early in the disease process [30], and they are associated with neuroinflammatory cells, a phenomenon also noted in brain. Similarly, work on the 3xTg model of AD indicated that tau tangles in addition to $A \beta$ plaques and gliosis occurs in the RGL pre-symptomatically and could potentially be used to 'predict' brain pathology in $\mathrm{AD}$ [14].

More recent studies demonstrate that hyperspectral imaging enables brain-relevant disease lesions to be evaluated in retina [15]. Changes in retinal reflectance spectra were found to correlate with brain $A \beta$ load in patients with mild cognitive impairment. Similar observations were made in $5 \mathrm{xFAD}$ mice, suggesting that retinal hyperspectral imaging may be a useful tool for predicting brain $A \beta$ load [15]. Responding to the rapidly expanding body of research linking ocular pathology and $\mathrm{AD}$ brain lesions, the American Alzheimer's Association convened a 'think tank' in mid-2019 aimed at establishing the foundations for population-based detection and monitoring of mild cognitive impairment and AD [37]. Other disorders for which retinal imaging is being explored as a screening/prognostic tool include Parkinson's disease 

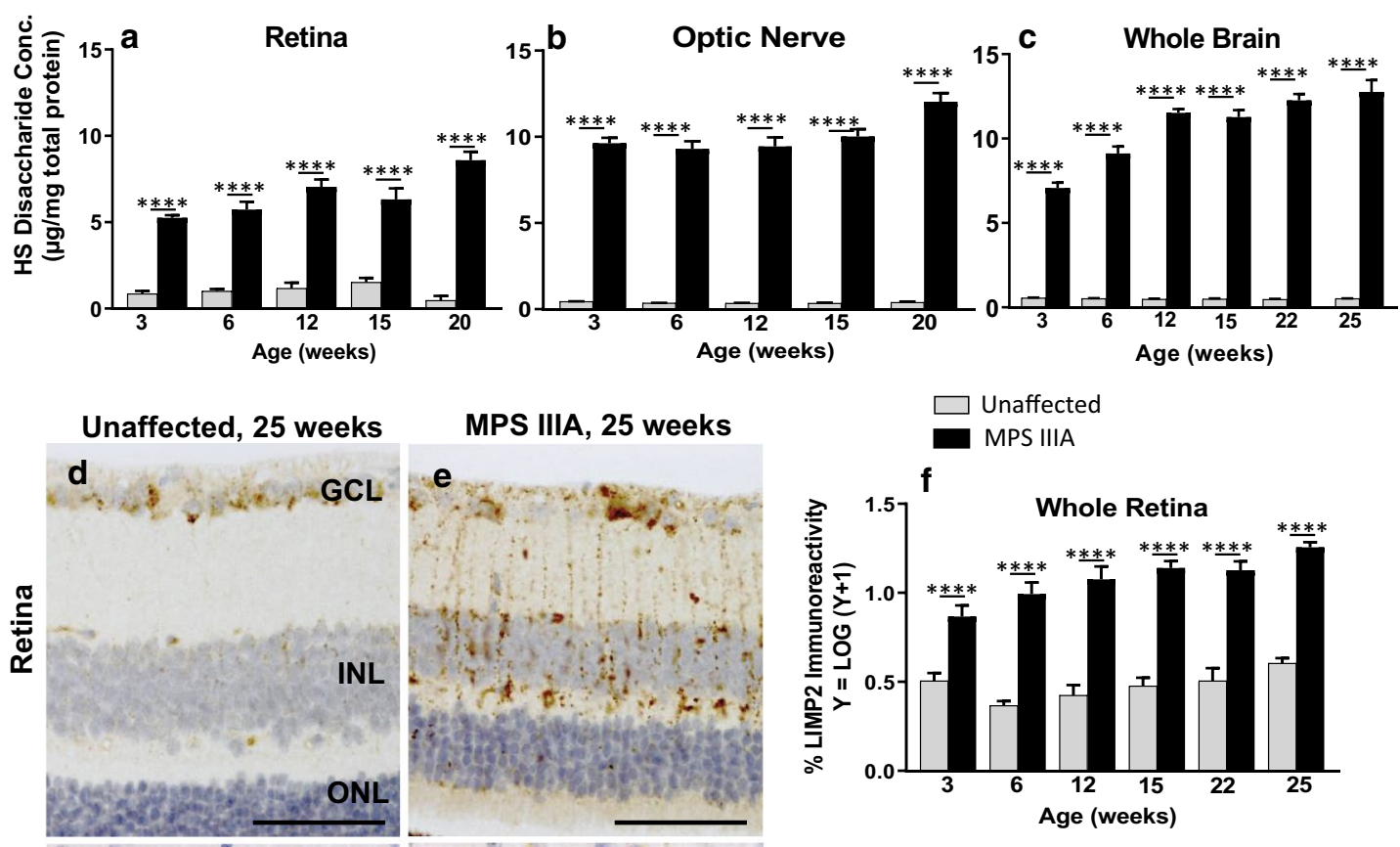

MPS IIIA, 25 weeks
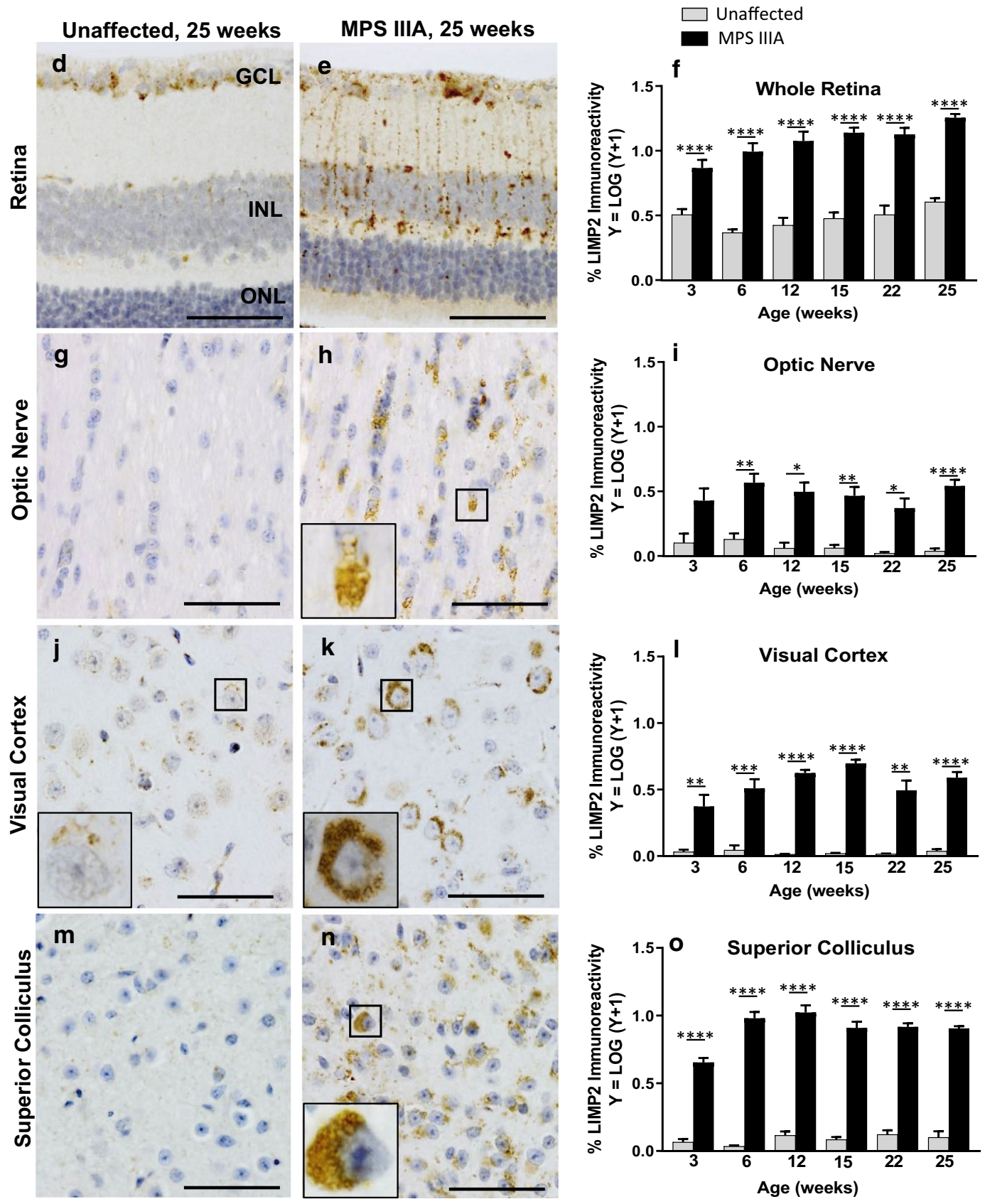


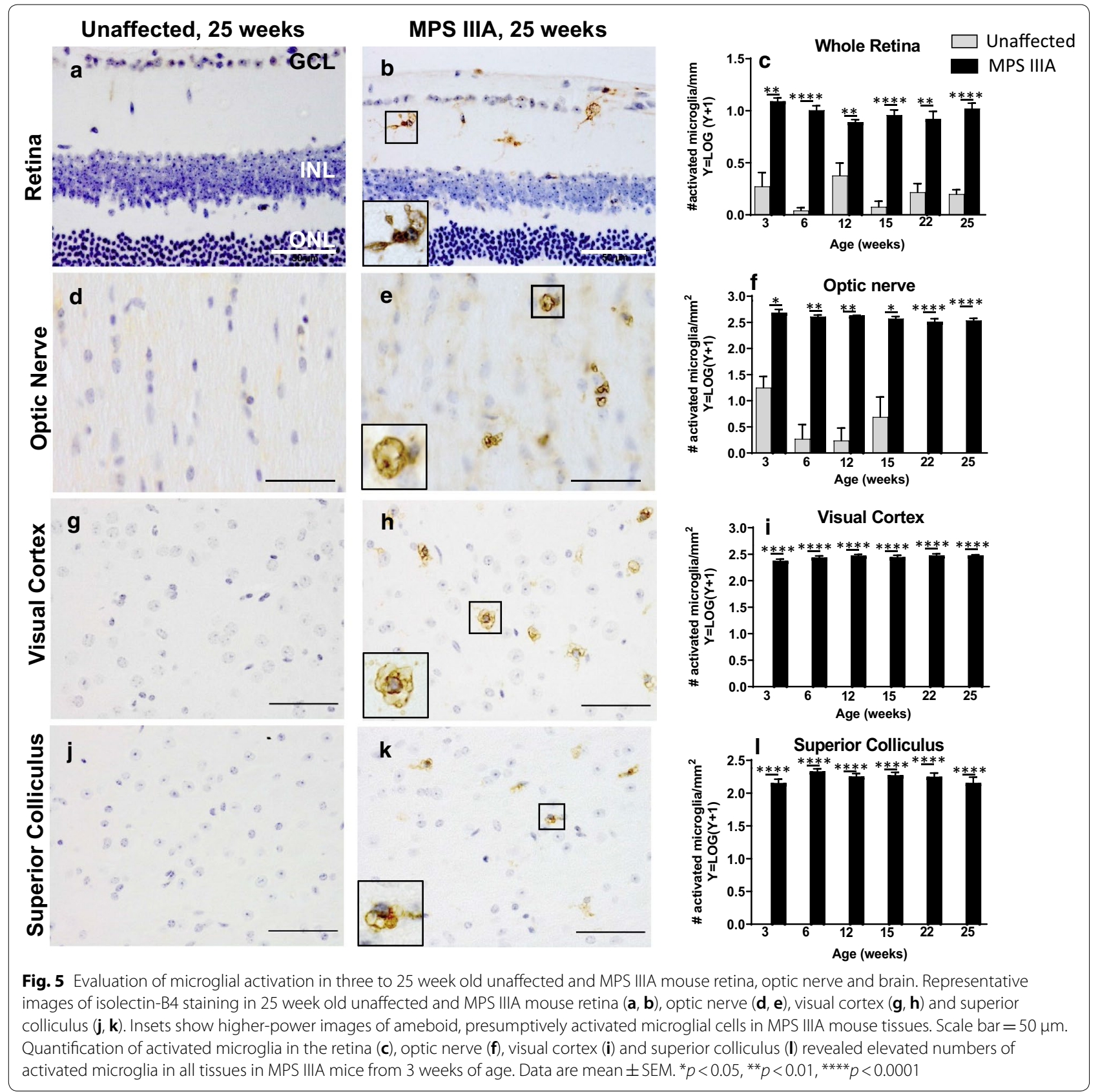

[20], psychiatric diseases including schizophrenia, bipolar disorder and major depressive disorder [39] and multiple sclerosis [25].

The second novel outcome of our study is the characterisation of retinal lesions present very early in the MPS III disease course, i.e. pre-symptomatically. Other studies have only evaluated Sanfilippo retina from a symptomatic stage onwards $(12+$ weeks $[21,42])$. We observed apoptotic (TUNEL-positive) cells and shortening of photoreceptor outer segments in both central and peripheral retina from 6 weeks of age, followed by loss of inner segments and profound, progressive loss of photoreceptor cell bodies 12 weeks of age in MPS IIIA mice. Both rod and $\mathrm{PNA}^{+}$-cone photoreceptor cells are impacted. Tools capable of visualising these very early apoptotic events and/or detecting initial loss of outer segments may provide prognostic indicators of the early-onset form of Sanfilippo c.f. later-onset disease that manifests in adulthood [29].

Other than photoreceptors, all other neuronal classes in the retina, including RGCs, bipolar cells, horizontal cells 


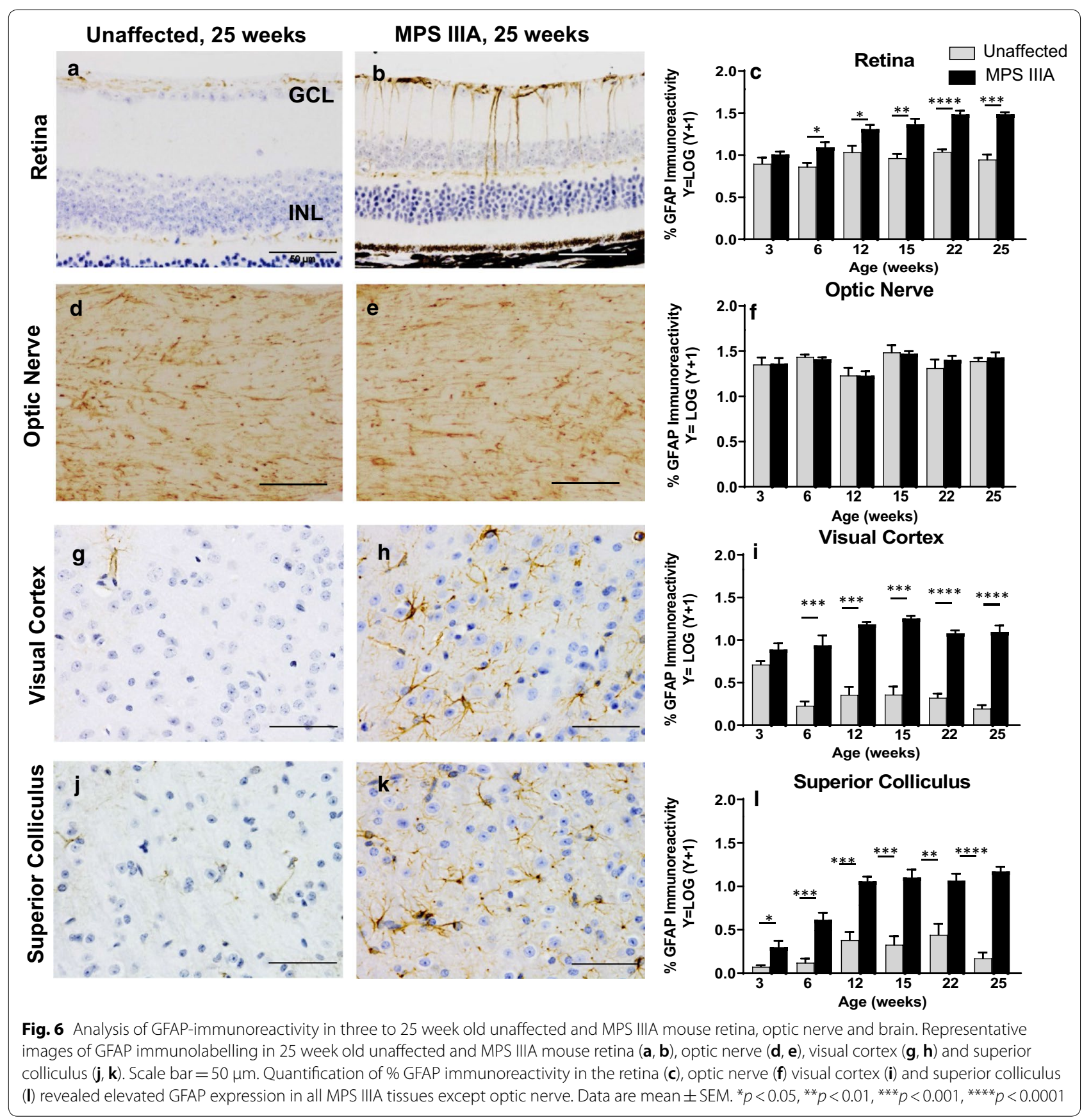

and amacrine cells, appear largely unaffected by the disease process. These parallels observations made in MPS IIIA mouse brain tissue: neither we [4], nor others [44] have been able to document neuron loss to very late disease stages (9 months of age). Therefore, apart from photoreceptors which must be acknowledged to be a highly specialised class of neuron, all other neurons in the retina and brain remain intact throughout the symptomatic stages of the disease process. Our observations are compatible with those reported in MPS IIIB mice by Heldermon et al. [18], who showed visible thinning of the ONL between eight and 16 weeks of age, and with those of Intartaglia et al. [21] who have recently described ONL thickness reductions and loss of photoreceptor outer segments at later stages in MPS IIIA mice ( $\sim 6$ months of age) and likewise reported minimal involvement of other retinal cell types. 

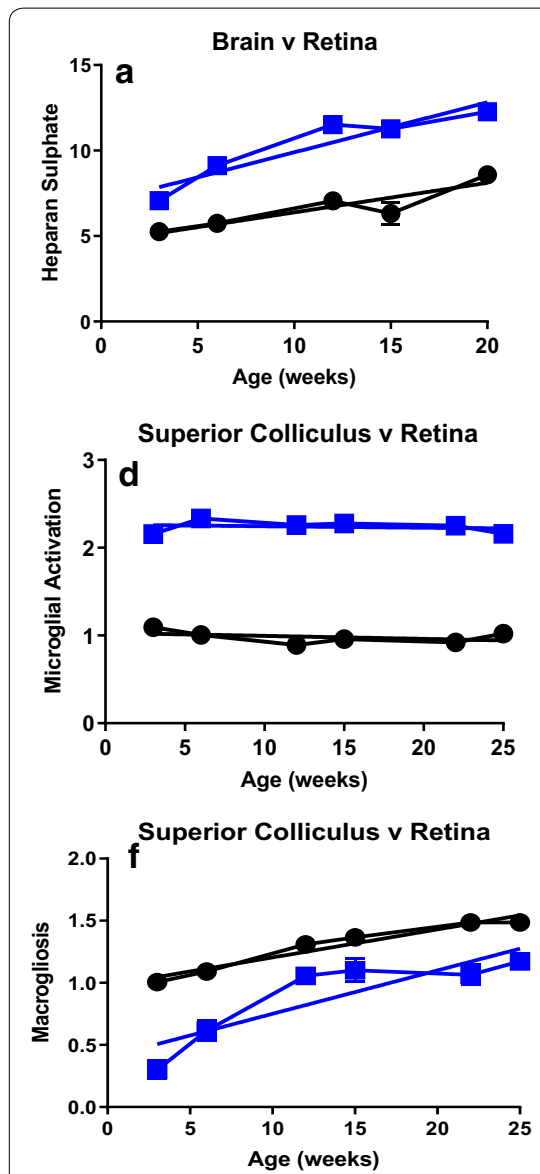
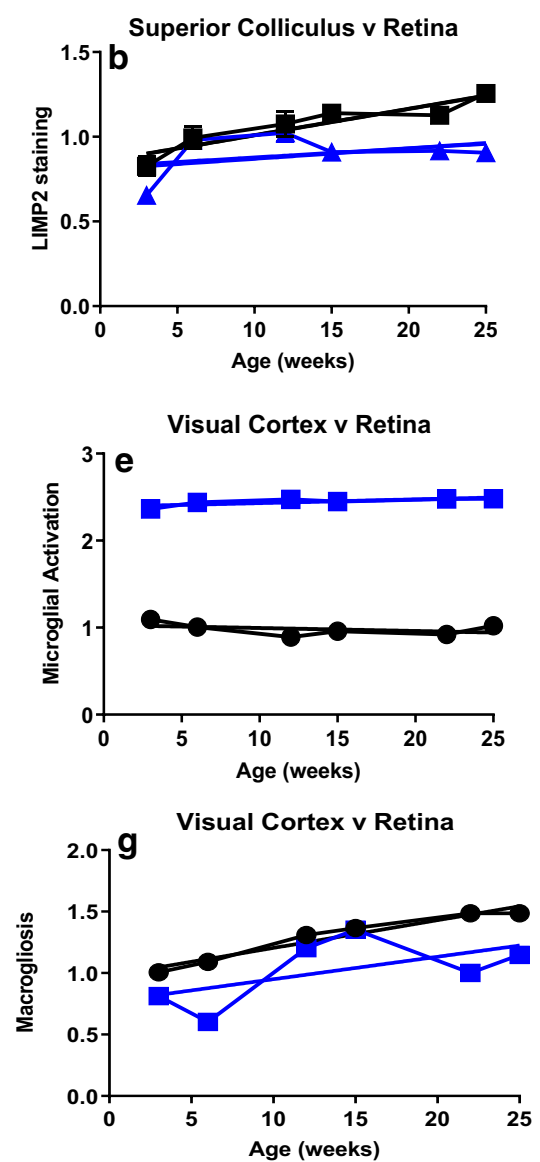
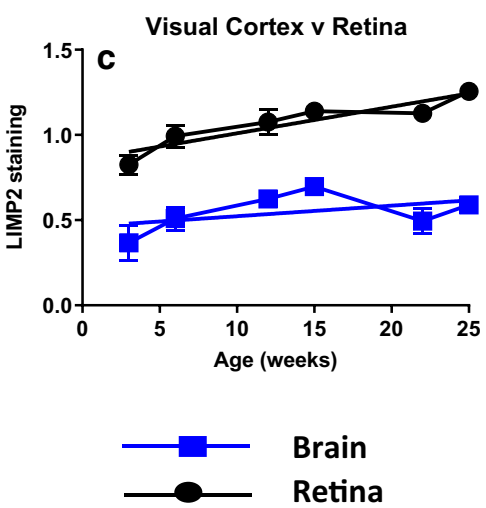

\begin{tabular}{|c|c|c|}
\hline Comparison & $\begin{array}{l}\text { Are the } \\
\text { slopes } \\
\text { equal? }\end{array}$ & $\begin{array}{c}P \\
\text { value }\end{array}$ \\
\hline HS in brain $v$ retina & Yes & 0.1732 \\
\hline $\begin{array}{l}\text { LIMP2 in superior } \\
\text { colliculus } v \text { retina }\end{array}$ & No & $0.0272(*)$ \\
\hline $\begin{array}{l}\text { LIMP2 - visual cortex v } \\
\text { retina }\end{array}$ & Yes & 0.2036 \\
\hline $\begin{array}{l}\text { Microgliosis - superior } \\
\text { colliculus v retina }\end{array}$ & Yes & 0.7586 \\
\hline $\begin{array}{l}\text { Microgliosis - visual } \\
\text { cortex } v \text { retina }\end{array}$ & Yes & 0.1046 \\
\hline $\begin{array}{l}\text { Macrogliosis - superior } \\
\text { colliculus v retina }\end{array}$ & Yes & 0.2685 \\
\hline $\begin{array}{l}\text { Macrogliosis - visual } \\
\text { cortex v retina }\end{array}$ & Yes & 0.7543 \\
\hline
\end{tabular}

Fig. 7 Relationship between the age of onset and rate of accumulation of disease lesions in the MPS IIIA mouse brain (squares) and retina (circles). Data indicating enlargement of the LIMP2-positive endo/lysosomal compartment (a-c), presence of activated microglia (d, e) and elevated expression of GFAP by macroglia $(\mathbf{f}, \mathbf{g})$ is shown. The slope of the lines was compared, and $p$ values have been tabulated

Loss of rod photoreceptors presumptively leads to the impairments previously noted in the dark-adapted ERG in MPS III mice [18, 21, 42]. Impaired or absent scotopic responses have also been described in patients with MPS III who exhibited night blindness [13]. Abnormalities in light-adapted ERGs were not noted in MPS IIIB mice aged up to 40 weeks of age [18] but became apparent by $\sim 1$ year [42]. The mechanism underlying photoreceptor cell death is at present unknown but may relate to impaired autophagosome/lysosome fusion which reduces autophagic flux [21].

In conclusion, this is the first study to evaluate the relationship between retinal and brain disease lesions in an animal model of a lysosomal storage disorder. We demonstrate that both retina and brain in Sanfilippo mice exhibit disease lesions at a very early disease stage (presymptomatic; 3 weeks of age) and that the rate of disease progression is comparable between the two structures. This bodes well for utilising non-invasive imaging of retina to inform our understanding of the state of brain disease. The loss of photoreceptor neurons during early disease progression and the possibility of visualising and monitoring this using non-invasive techniques may provide both a prognostic and therapeutic monitoring tool for MPS IIIA. At the very least, the early age at which retina displays disease lesions in Sanfilippo syndrome highlights the absolute necessity of directing therapeutics at both the brain and the retina, to ensure patient quality of life is maximised. 

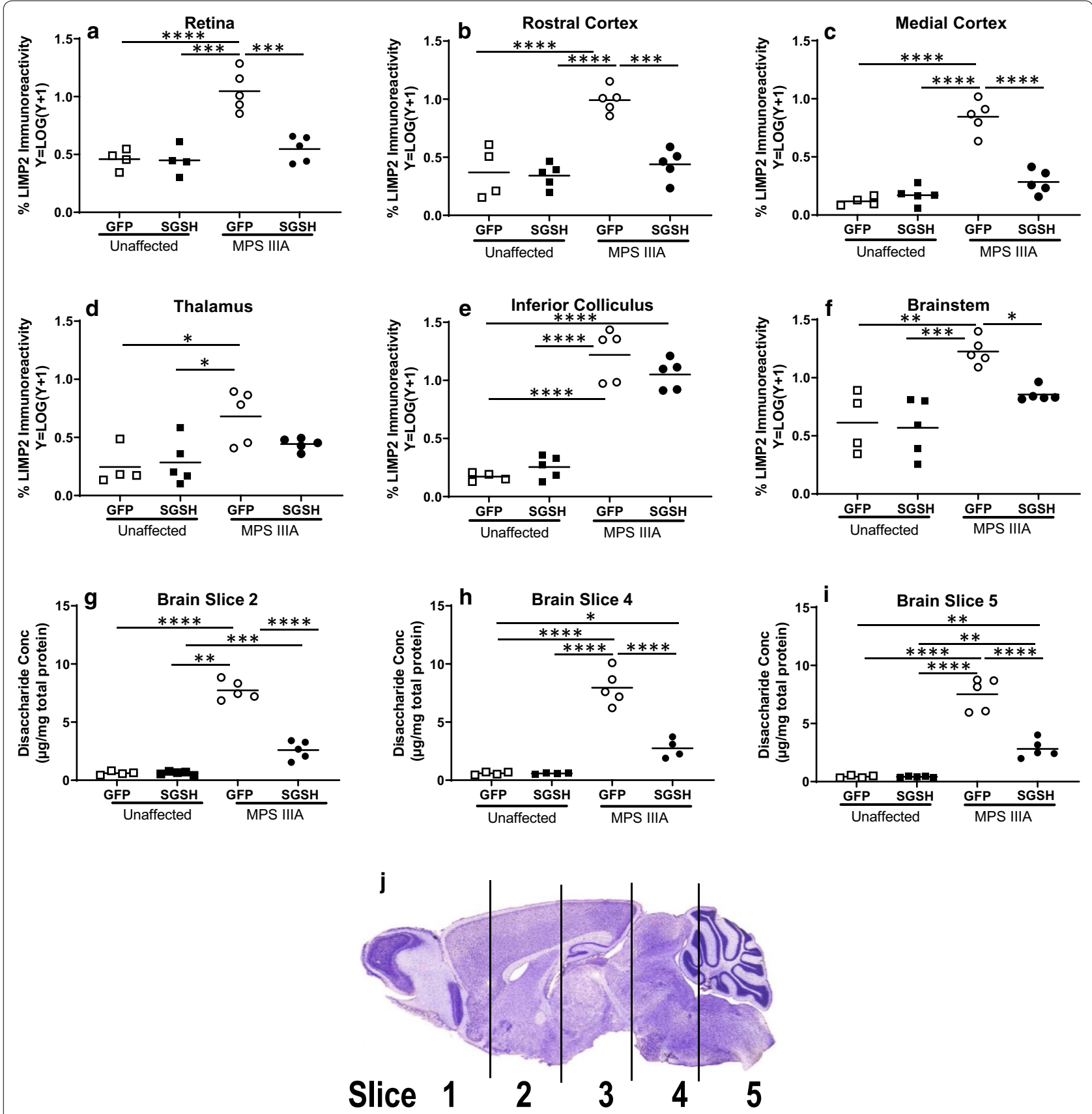

Fig. 8 AAV9-CMV-SGSH (or control vector) was delivered i.v. to mice on each of day 0 and day 5 of life and the impact on substrate accumulation in the endo/lysosomal compartment in mouse retina and brain was determined 6 weeks post-injection. \% LIMP2 immunoreactivity was evaluated in the retina $(\mathbf{a})$, rostral cortex $(\mathbf{b})$, medial cortex $(\mathbf{c})$, thalamus $(\mathbf{d})$, inferior colliculus (e) and brainstem (f). Accumulation of primary substrate (heparan sulphate) in brain slice 2,4 and 5 is shown in $\mathbf{g - i}$ ). The $2 \mathrm{~mm}$ thick brain slice protocol is shown in $\mathbf{j} .{ }^{*} p<0.05,{ }^{* *} p<0.01,{ }^{* * *} p<0.001,{ }^{* * * *} p<0.0001$ 


\section{Supplementary information}

Supplementary information accompanies this paper at https://doi. org/10.1186/s40478-020-01070-w.

Additional file 1: Figure S1. A-type retinal ganglion cells in unaffected Thy1-GFP (A) and MPS IIIA Thy1-GFP mouse retina (B). Scale bar $=50 \mu \mathrm{m}$. The complexity of the dendritic tree was determined in GFP-positive RGCs in unaffected and MPS IIIA mice aged three, six, 12, and 20 weeks of age. We observed no significant difference in dendritic tree area (C), total dendritic tree cable length (D), or the total number of branch points or nodes (E). Negligible change was observed in soma diameter over the 20 week time course (F). Data represent mean \pm SEM. ${ }^{*} \mathrm{p}<0.05$.

Additional file 2: Figure S2. Representative images of ubiquitin immunolabelling in 25 week old unaffected and MPS IIIA optic nerve are shown (A, B). Arrows indicate ubiquitin-positive spheroids. Scale bar $=20 \mu \mathrm{m}$. (C) Ubiquitin-positive axonal spheroids $>5 \mu \mathrm{m}$ diameter were quantified in optic nerve obtained from unaffected and MPS IIIA mice aged 3- to 25 -weeks of age. ${ }^{* * *} \mathrm{p}<0.0001$

\section{Acknowledgements}

We thank Dr Adeline Lau (Childhood Dementia Research Group) for developing the GFP genotyping assay, Sarah Tamang for mouse husbandry, monitoring and genotyping (formerly Childhood Dementia Research Group) and the Women's and Children's Health Network Animal Care Facility for routine care of our animals.

\section{Authors' contributions}

HB carried out the histological/immunohistological evaluations reported in the study, analysed and interpreted the data and made a substantial contribution to manuscript construction. GC was an Associate Investigator on the grant funding the research, was involved in experimental design, provided expert advice on histological/immunohistochemical evaluations and analysed and interpreted the data. He provided critical input to the manuscript. DN and NN carried out histological evaluations reported in the manuscript and analysed and interpreted the data. MD obtained the samples for the study, carried out the mass spectrometry-based assays in the manuscript and analysed and interpreted the data. PJT and MFS carried out the mass spectrometry reported in the manuscript and analysed and interpreted the data. DN, NN, MD, PJT and MFS provided expert input into manuscript construction. RJC and $\mathrm{KMH}$ designed the experiments, obtained the funding for the study and analysed and interpreted the data. RJC offered expert input into manuscript construction. $\mathrm{KMH}$ supervised the study and wrote the manuscript. All authors have read, edited and approved the submitted version of the manuscript and have agreed to be personally accountable for their own contributions and to ensure that questions related to the accuracy or integrity of any part of the work are appropriately investigated, resolved, and the resolution documented in the literature.

\section{Funding}

The study was funded by a Project Grant from the Australian National Health and Medical Research Council (NHMRC) to KMH and RJC (\#1121522). The funding body had no role in the design of the study or the collection, analysis, and interpretation of data. The funding body had no role in writing the manuscript.

\section{Availability of data and materials}

The datasets created during the current study are available from the corresponding author on reasonable request. No publicly available data was used in the manuscript.

\section{Ethics approval and consent to participate}

A statement on the animal ethics approvals obtained prior to commencement of this study has been included in the manuscript. All breeding, housing and experimental procedures complied with the Australian code for the care and use of animals for scientific purposes (8th edition; 2013) and the Association for Research in Vision and Ophthalmology (ARVO) statement (2016).

\section{Consent for publication}

Not applicable. This manuscript does not contain data from any individual person.

\section{Competing interests}

The authors declare that they have no competing interests.

\section{Author details}

${ }^{1}$ Childhood Dementia Research Group, Hopwood Centre for Neurobiology, Lifelong Health Theme, South Australian Health and Medical Research Institute, Adelaide, SA, Australia. ${ }^{2}$ Present Address: Childhood Dementia Research Group, College of Medicine and Public Health, Finders Health and Medical Research Institute (FHMRI), Flinders University, Bedford Park, SA, Australia.

${ }^{3}$ Ophthalmic Research Laboratories, Discipline of Ophthalmology and Visual Sciences, University of Adelaide, Adelaide, SA, Australia. ${ }^{4}$ Proteomics, Metabolomics and MS-Imaging Facility, South Australian Health and Medical Research Institute, Adelaide, SA, Australia.

Received: 6 October 2020 Accepted: 28 October 2020

Published online: 17 November 2020

\section{References}

1. Almonte MT, Capellàn P, Yap TE, Cordeiro MF (2020) Retinal correlates of psychiatric disorders. Ther Adv Chronic Dis 11:2040622320905215

2. Alpar A, Palm K, Schierwagen A, Arendt T, Gartner U (2003) Expression of constitutively active p21Hrasval 12 in postmitotic pyramidal neurons results in increased dendritic size and complexity. J Comp Neurol 467:119-133

3. Ashworth JL, Biswas S, Wraith E, Lloyd IC (2006) Mucopolysaccharidosis and the eye. Surv Ophthalmol 51:1-17

4. Beard H, Hassiotis S, Gai WP, Parkinson-Lawrence E, Hopwood JJ, Hemsley KM (2017) Axonal dystrophy in the brain of mice with Sanfilippo syndrome. Exp Neurol 295:243-255

5. Byrne LC, Lin YJ, Lee T, Schaffer DV, Flannery JG (2015) The expression pattern of systemically injected AAV9 in the developing mouse retina is determined by age. Mol Ther 23:290-296

6. Ceuterick C, Martin JJ, Libert J, Farriaux JP (1980) Sanfilippo A disease in the fetus-comparison with pre- and postnatal cases. Neuropadiatrie 11:76-185

7. Chidlow G, Wood JP, Manavis J, Finnie J, Casson RJ (2017) Investigations into retinal pathology in the early stages of a mouse model of Alzheimer's disease. J Alzheimers Dis 56(2):655-675

8. Connor K, Krah N, Dennison R, Aderman C, Chen J, Guerin K et al (2009) Quantification of oxygen-induced retinopathy in the mouse: a model of vessel loss, vessel regrowth and pathological angiogenesis. Nat Protoc 4:1565-1573

9. Del Monte MA, Maumenee IH, Green WR, Kenyon KR (1983) Histopathology of Sanfilippo's syndrome. Arch Ophthalmol 101:1255-1262

10. Feng G, Mellor RH, Bernstein M, Keller-Peck C, Nguyen QT, Wallace M et al (2000) Imaging neuronal subsets in transgenic mice expressing multiple spectral variants of GFP. Neuron 28:41-51

11. Fu H, Cataldi MP, Ware TA, Zaraspe K, Meadows AS, Murrey DA et al (2016) Functional correction of neurological and somatic disorders at later stages of disease in MPS IIIA mice by systemic sCAAV9-hSGSH gene delivery. Mol Ther Methods Clin Dev 3:16036

12. Gavrieli Y, Sherman Y, Ben-Sasson SA (1992) Identification of programmed cell death in situ via specific labeling of nuclear DNA fragmentation. J Cell Biol 119:493-501

13. Gills JP, Hobson R, Hanley WB, McKusick VA (1965) Electroretinography and fundus oculi findings in Hurler's disease and allied mucopolysaccharidoses. Arch Ophthalmol 74:596-603

14. Grimaldi A, Brighi C, Peruzzi G, Ragozzino D, Bonanni V, Limatola C et al (2018) Inflammation, neurodegeneration and protein aggregation in the retina as ocular biomarkers for Alzheimer's disease in the 3xTg-AD mouse model. Cell Death Dis 9(6):685

15. Hadoux X, Hui F, Lim JKH, Masters CL, Pébay A, Chevalier S et al (2019) Non-invasive in vivo hyperspectral imaging of the retina for potential biomarker use in Alzheimer's disease. Nat Commun 10(1):4227 
16. Haer-Wigman L, Newman H, Leibu R, Bax NM, Baris HN, Rizel L et al (2015) Non-syndromic retinitis pigmentosa due to mutations in the mucopolysaccharidosis type IIIC gene, heparan-alpha-glucosaminide $\mathrm{N}$-acetyltransferase (HGSNAT). Hum Mol Genet 24:3742-3751

17. Hassiotis S, Beard H, Luck A, Trim PJ, King B, Snel MF et al (2014) Disease stage determines the efficacy of treatment of a paediatric neurodegenerative disease. Eur J Neurosci 39(12):2139-2150

18. Heldermon CD, Hennig AK, Ohlemiller KK, Ogilvie JM, Herzog ED, Breidenbach A et al (2007) Development of sensory, motor and behavioral deficits in the murine model of Sanfilippo syndrome type B. PLoS ONE 2(8):e772

19. Hocquemiller M, Hemsley KM, Douglass ML, Tamang SJ, Neumann D, King BM et al (2019) AAVrh10 vector corrects disease pathology in MPS IIIA mice and achieves widespread distribution of SGSH in large animal brains. Mol Ther Methods Clin Dev 17:174-187

20. Huang L, Wang C, Wang W, Wang Y, Zhang R (2020) The specific pattern of retinal nerve fiber layer thinning in Parkinson's disease: a systematic review and meta-analysis. J Neurol. https://doi.org/10.1007/s0041 5-020-10094-0

21. Intarglia D, Giamundo G, Marrocco E, Maffia V, Salierno FG, Nusco E et al (2020) Retinal degeneration in MPS-IIIA mouse model. Front Cell Dev Biol 8:132

22. Koronyo-Hamaoui M, Koronyo Y, Ljubimov AV, Miller CA, Ko MK, Black KL et al (2011) Identification of amyloid plaques in retinas from Alzheimer's patients and non-invasive in vivo optical imaging of retinal plaques in a mouse model. Neuroimage 54(Suppl 1):S204-S217

23. Koronyo Y, Biggs D, Barron E, Boyer DS, Pearlman JA, Au WJ et al (2017) Retinal amyloid pathology and proof-of-concept imaging trial in Alzheimer's disease. JCI Insight 2(16):e93621

24. Krantic S, Torriglia A (2014) Retina: source of the earliest biomarkers for Alzheimer's disease? J Alzheimers Dis 40:237-243

25. Lambe J, Murphy OC, Saidha S (2018) Can optical coherence tomography be used to guide treatment decisions in adult or pediatric multiple sclerosis? Curr Treat Options Neurol 20(4):9

26. Lau AA, Shamsani NJ, Winner LK, Hassiotis S, King BM, Hopwood JJ et al (2013) Neonatal bone marrow transplantation in MPS IIIA mice. JIMD Rep 8:121-132

27. Lavery MA, Green WR, Jabs EW, Luckenbach MW, Cox JL (1983) Ocular histopathology and ultrastructure of Sanfilippo's syndrome, type III-B. Arch Ophthalmol 101:1263-1274

28. Meikle PJ, Hopwood JJ, Clague AE, Carey WF (1999) Prevalence of lysosomal storage disorders. JAMA 281:249-254

29. Nijmeijer SCM, van den Born LI, Kievit AJA, Stepien KM, Langendonk J, Marchal JP et al (2019) The attenuated end of the phenotypic spectrum in MPS III: from late-onset stable cognitive impairment to a non-neuronopathic phenotype. Orphanet J Rare Dis 14(1):249

30. Nilson AN, English KC, Gerson JE, Barton Whittle T, Nicolas Crain C, Xue J et al (2017) Tau oligomers associate with inflammation in the brain and retina of tauopathy mice and in neurodegenerative diseases. J Alzheimers Dis 55(3):1083-1099
31. Palmieri C, Giger U, Wang P, Pizarro M, Shivaprasad HL (2015) Pathological \& biochemical studies of MPS IIIB (Sanfilippo syndrome type B) in juvenile emus (Dromaius novaehollandiae). Vet Pathol 52:160-169

32. Paxinos G, Franklin KBJ (2001) The mouse brain in stereotaxic Co-ordinates. Academic Press, New York

33. Portera-Cailliau C, Sung CH, Nathans J, Adler R (1994) Apoptotic photoreceptor cell death in mouse models of retinitis pigmentosa. Proc Natl Acad Sci USA 91:974-978

34. Saha S, Greferath U, Vessey KA, Grayden DB, Burkitt AN, Fletcher EL (2016) Changes in ganglion cells during retinal degeneration. Neuroscience 329:1-11

35. Schiff ER, Varela MD, Robson AG, Pierpoint K, Ba-Abbad R, Nutan S et al (2020) A genetic and clinical study of individuals with nonsyndromic retinopathy consequent upon sequence variants in HGSNAT, the gene associated with Sanfilippo C mucopolysaccharidosis. Am J Med Genet C Semin Med Genet. https://doi.org/10.1002/ajmg.c.31822

36. Schindelin J, Arganda-Carreras I, Frise E, Kaynig V, Longair M, Pietzch T et al (2012) Fiji: an open-source platform for biological-image analysis. Nat Methods 9(7):676-682

37. Snyder PJ, Snyder HM, Bain LJ (2020) Retinal imaging think tank convened by the Alzheimer's association to examine its promise in the early detection of Alzheimer's. Alzheimers Dement 16(1):244

38. Sun W, Li N, He S (2002) Large-scale of morphological survey of mouse retinal ganglion cells. J Comp Neurol 451:115-126

39. Tan A, Schwitzer T, Conart JB, Angioi-Duprez K (2020) Study of retinal structure and function in patients with major depressive disorder, bipolar disorder or schizophrenia: A review of the literature. J Fr Ophthalmol 43(5):e157-e166

40. Tardieu M, Zérah M, Husson B, de Bournonville S, Deiva K, Adamsbaum C et al (2014) Intracerebral administration of adeno-associated viral vector serotype rh.10 carrying human SGSH and SUMF1 cDNAs in children with mucopolysaccharidosis type IIIA disease: results of a phase I/II trial. Hum Gene Ther 25:506-516

41. Trim PJ, Hopwood JJ, Snel MF (2015) Butanolysis derivatization: improved sensitivity in LC-MS/MS quantitation of heparan sulfate in urine from mucopolysaccharidosis patients. Anal Chem 87:9243-9250

42. Tse DY, Lotfi P, Simons DL, Sardiello M, Wu SM (2015) Electrophysiological and histological characterization of rod-cone retinal degeneration \& microglia activation in MPS IIIB. Sci Rep 5:17143

43. Valstar MJ, Neijs S, Bruggenwirth HT, Olmer R, Ruijter GJ, Wevers RA et al (2010) Mucopolysaccharidosis type IIIA: clinical spectrum and genotypephenotype correlations. Ann Neurol 68:876-887

44. Wilkinson FL, Holley RJ, Langford-Smith KJ, Badrinath S, Liao A, LangfordSmith A et al (2012) Neuropathology in mouse models of mucopolysaccharidosis type I, IIIA and IIIB. PLoS ONE 7(4):e35787

\section{Publisher's Note}

Springer Nature remains neutral with regard to jurisdictional claims in published maps and institutional affiliations.
Ready to submit your research? Choose BMC and benefit from:

- fast, convenient online submission

- thorough peer review by experienced researchers in your field

- rapid publication on acceptance

- support for research data, including large and complex data types

- gold Open Access which fosters wider collaboration and increased citations

- maximum visibility for your research: over 100M website views per year

At BMC, research is always in progress.

Learn more biomedcentral.com/submissions 